\title{
Floriane Place-Verghens, Jeux pragmatiques dans les "Contes et Nouvelles» de guy de Maupassant
}

\section{Ida Merello}

\section{(2) OpenEdition}

1 Journals

\section{Edizione digitale}

URL: http://journals.openedition.org/studifrancesi/30647

DOI: 10.4000/studifrancesi.30647

ISSN: 2421-5856

\section{Editore}

Rosenberg \& Sellier

\section{Edizione cartacea}

Data di pubblicazione: 1 avril 2006

Paginazione: 186

ISSN: 0039-2944

\section{Notizia bibliografica digitale}

Ida Merello, «Floriane Place-Verghens, Jeux pragmatiques dans les «Contes et Nouvelles» de guy de Maupassant», Studi Francesi [Online], 148 (XLX | I) | 2006, online dal 30 novembre 2015, consultato il 20 avril 2021. URL: http://journals.openedition.org/studifrancesi/30647 ; DOI: https://doi.org/10.4000/ studifrancesi.30647

Questo documento è stato generato automaticamente il 20 avril 2021.

\section{(c) (1)}

Studi Francesi è distribuita con Licenza Creative Commons Attribuzione - Non commerciale - Non opere derivate 4.0 Internazionale. 


\title{
Floriane Place-Verghens, Jeux pragmatiques dans les «Contes et Nouvelles» de guy de Maupassant
}

\author{
Ida Merello
}

\section{NOTIZIA}

FLORIANE PLACE-VERGHENS, Jeux pragmatiques dans les «Contes et Nouvelles» de guy de Maupassant, Paris, Champion 2005, pp. 335.

1 Il lavoro, rigorosamente narratologico, descrive le strutture delle novelle di Maupassant a partire dal paratesto i titoli, i sottotitoli, i prologhi e quant'altro per poi affrontare la narrazione, le sue funzioni, quelle dei vari narratori e narratari. A termine della minuziosa analisi, la conclusione è che i racconti di Maupassant hanno una semplicità solo apparente e sono sempre pensati in funzione di un lettore. Più interessante forse l'inquadramento delle diverse conclusioni delle novelle in sette tipi di procedimento. In appendice un'utile tabella delle dediche di Maupassant con indicazioni sui destinatari e una tassonomia dei personaggi, suddivisi per arrivisti, donne di mondo, prostitute, uomini influenti, di cui si citano osservazioni riguardanti il fisico, la vita interiore, l'ambiente, gli abiti, le capacità oratorie e i "codici sociali", ossia il modo di comportarsi in pubblico. 